\title{
AUDIENCIAS INFANTILES:
}

\section{SUS CONTEXTOS DE RECEPCIÓN}

Por:

\author{
Maritza López \\ Profesora Titular \\ Escuela de Comunicación Social de la \\ Facultad de Artes Integradas \\ Universidad del Valle, Cali, Colombia \\ maritzaldelar@hotmail.com
}

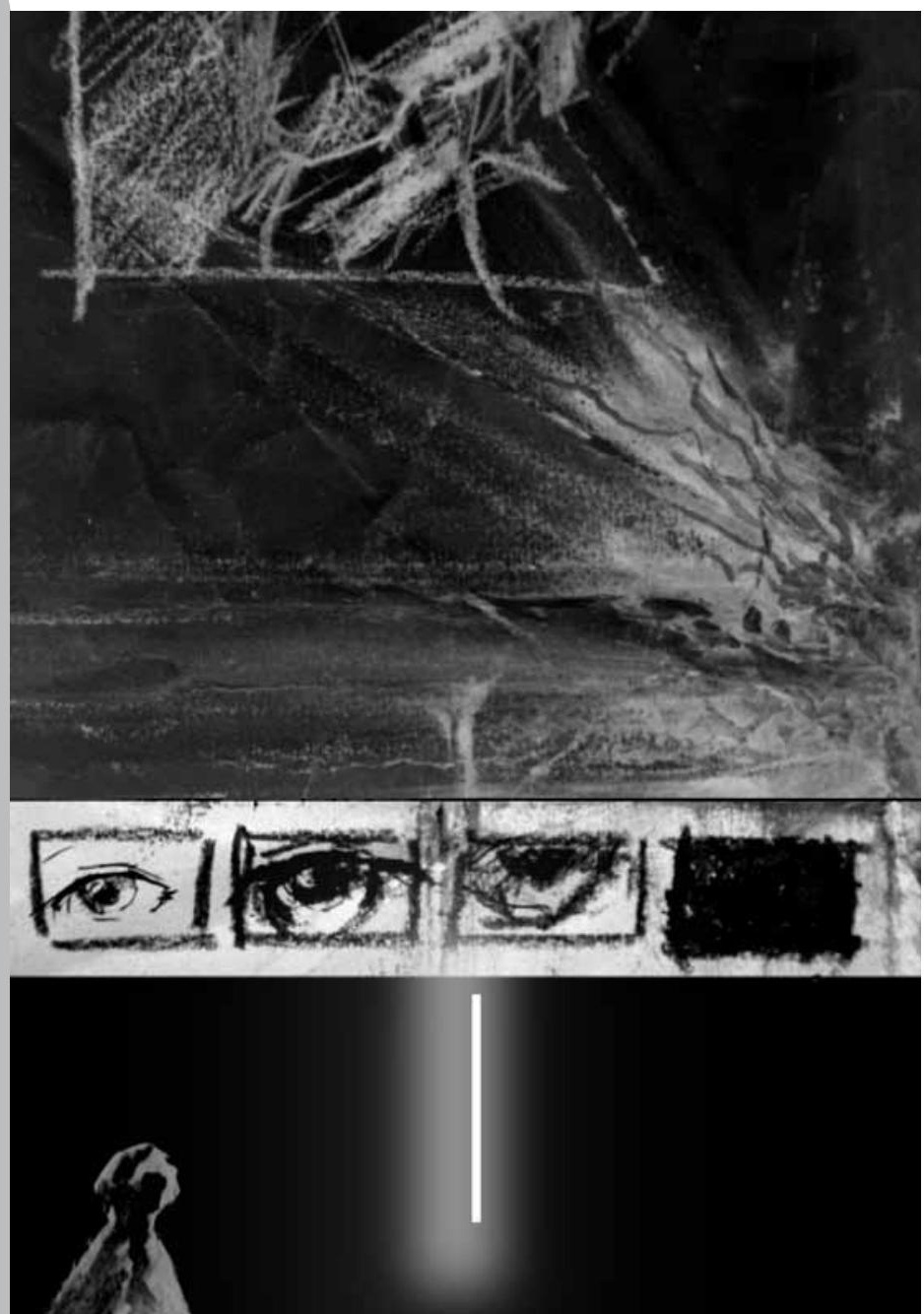

\section{Resumen:}

Este artículo describe los hábitos de consumo de medios y de otros bienes culturales en el marco del tiempo libre de audiencias infantiles diferenciadas. Se presentan a la par una serie de argumentos y de datos empíricos acerca de cómo los niños y niñas se relacionan con los noticieros de TV, con la noción de "información", y con determinados hechos y personajes publicitados profusamente por los medios. El texto incorpora datos y análisis de dos fases de una misma investigación, desarrolladas en 2004-2005 la primera, y en 2007-2008 la segunda.

Las diferenciaciones en cuanto al tipo de medios masivos, programas y textos con los cuales cada grupo de niños y niñas se relaciona cotidianamente interesan aquí en función de cómo es la recepción de la oferta mediática por diferentes grupos sociales, incluidos el pueblo indígena Guambiano y varias comunidades afrodescendientes. Además, registrar la recepción diferenciada es relevante, en tanto esto permite rastrear los procesos desiguales de distribución del conocimiento y cómo se gesta la socialización política de las nuevas generaciones.

\section{Palabras clave:}

Audiencias infantiles, Capital escolar, Representaciones sociales, Medios, Recepciones. 


\section{¿Cómo son las relaciones de los niños y las niñas con las noticias de la $\mathrm{TV}^{2}$ ?}

La investigación que sustenta este artículo examina la influencia de los medios masivos, y principalmente de la televisión, en las construcciones de la realidad que hacen los niños y las niñas. Dos fases de trabajo de campo, las cuales son el fundamento del análisis, cumplieron las labores de identificar, describir e interpretar imágenes y discursos de los medios que se han grabado en las memorias de los menores participantes, y son reproducidos en lo que hablan, en sus ideas sobre el mundo y en sus interacciones. Las diversas representaciones sociales no serán abordadas aquí, ya que este texto se concentrará en la descripción de lo que la perspectiva culturalista ha denominado el "social setting", o lugar social dentro del cual se realizan los procesos de interacción entre sujetos y medios ${ }^{3}$.

La investigación aludida reconoce y documenta diversas "mediaciones" que intervienen en las "representaciones sociales", es decir, en las ideas que construyen los niños y las niñas a través de su contacto diario con la TV. Las "mediaciones", podemos considerarlas como "factores" o "variables" que contribuyen a dar determinada forma a las interpretaciones de los mensajes de los medios, y operan en la medida en que un niño o niña pertenezca a una clase social, a una etnia, asuma una particular identidad de género, haya acumulado o no capital ecolar, sea influido por alguna ideología familiar, esté situado en cierta ubicación geográfica, y viva en la ciudad o en el campo, entre otras ${ }^{4}$.

Se hará un resumen de cómo son las relaciones de diferentes grupos de niños colombianos, socioculturalmente diferenciados, con los medios de comunicación; y se analizará el conocimiento que tienen sobre determinados temas, algunos de los cuales son incluidos frecuentemente en las agendas de los medios. Esta parte es el "contexto de la recepción” e incluirá elementos para evaluar cómo son sus relaciones con los géneros informativos. Se ha considerado pertinente introducir dicho tema

específico por dos razones. La primera es que este trabajo se interesa por la socialización política de las nuevas generaciones. La segunda, porque aunque los menores no son espectadores asiduos de noticieros, ni los ven por su propia voluntad, el examen de sus relaciones con este género permitirá conocer algo acerca de cómo ocurren los procesos de distribución del conocimiento social a través de los medios, y además aportar elementos para la comprensión del origen de algunas de sus representaciones sociales, que pueden estar influidas por la información noticiosa y los diálogos cotidianos acerca de los hechos de actualidad.

El texto se organiza tomando en cuenta la agrupación de todos los niños participantes en dos grandes categorías diferenciadas: niños con capital escolar restringido (CER) y niños con capital escolar ampliado (CEA). Dichas categorías se utilizan en el análisis y se explican en la nota final de este artículo. Se advierte, sin embargo, que al interior de cada una de tales categorías se señalan diferenciaciones importantes que son explicadas aquí, aunque parcialmente por las limitaciones de espacio. La información cuantitativa citada proviene de la encuesta que hizo parte del trabajo de campo durante 2007-2008. Se aplicó a 130 niños en total, con edades entre los 7 y 12 años. Se encuestaron 60 niños en Bogotá, 39 en Puerto Tejada y 31 en Guambía. Todos los niños encuestados participaron en los talleres realizados como parte del trabajo empírico. 


\section{¿Aprenden los niños y las niñas con la televisión?}

El conflicto armado ocupa el primer lugar en cuanto a los tópicos con los cuales los niños colombianos están familiarizados y que hacen parte de su memoria, incluidas las referencias al ejército. Sin embargo, para los niños rurales -del pequeño poblado de Zaragoza cercano al Litoral Pacífico del Valle, y del pueblo indígena guambiano en el Cauca- lo que saben acerca de la guerrilla y el ejército se deriva de su experiencia inmediata. Es decir, es una realidad local. Al referirse a los soldados afirman que "Pasan por aquí (...) nos protegen”, y “Están abajo, más lejos de Silvia”. El ejército y la guerrilla son conocimientos de su ámbito cotidiano. Entonces los niños rurales contrastan radicalmente con los urbanos en cuanto a sus percepciones del conflicto armado, pues los niños de las ciudades se enteran de la guerra en Colombia es a través de la pantalla del televisor.

En este sentido la ubicación geográfica también opera como mediación cuando los niños manifiestan sus preferencias por determinados temas de las noticias que se transmiten en los noticieros de TV. De acuerdo con los resultados de la fase 2 del trabajo de campo, las noticias del conflicto armado generan mayor interés entre los niños de Guambía y de Puerto Tejada (33,3\% cada uno) que entre los niños de Bogotá $(8,1 \%)$, muy seguramente porque en los dos primeros casos este tipo de noticias hacen parte de su realidad local. Los niños de Zaragoza no fueron consultados en la fase 2. De ahí que no aparezcan preferencias de ellos sobre noticias de guerra, aunque están localizados en una zona de combates.

Los niños urbanos -de Cali, Bogotá y el municipio de Puerto Tejada en el Cauca ${ }^{5}$ - nombran a la TV como la fuente principal de lo que saben sobre el conflicto armado, y de hecho la oferta diaria de imágenes y discursos sobre el ejército y la guerrilla es grande en las diversas emisiones y segmentos de los canales comerciales nacionales, de los canales administrados por el Estado, y de los canales regionales: en los noticieros, en las cuñas publicitarias, en algunos dramatizados. Sin embargo, también debe contemplarse que los términos de "ejército" y "guerrilla" se han vuelto parte de las conversaciones cotidianas en la sociedad colombiana, de tal modo que hay que asumirlas como representaciones puestas en circulación por los sistemas de medios, pero también internalizadas por los grupos sociales y que hacen parte de los intercambios lingüísticos comunes. Debe registrarse, sin embargo, que los niños pertenecientes al grupo de afrocolombianos de sectores populares de Cali no respondieron adecuadamente al ser preguntados sobre el ejército. Su percepción de la guerra también es precaria, e identificaron "los gobernantes" con los policías que ven en las calles de su barrio. Un dato significativo que hay que tener en cuenta es que, con escasas excepciones, todos los niños asignan sentidos negativos a la guerrilla. Aparecen definidos como "ejército malo", "asesinos", personas que “matan”, y “amenazan”. Y los niños los relacionan con “secuestros”. ${ }^{6}$

La mayoría de los niños y niñas participantes en los talleres saben con claridad que en Colombia hay un conflicto armado ${ }^{7}$. En contraste, la condición de "desplazado", o de refugiado interno, una consecuencia de la guerra, es un fenómeno social sobre el cual los niños no saben o tienen una percepción confusa. Pocos de ellos, todos de capital escolar ampliado, asocian el "desplazamiento forzado interno" con el éxodo de personas de su lugar de origen por causa de la presión de grupos armados. Los otros simplemente le asignan el significado de "gente en la calle, pobres", que coincide con los avisos que ha publicitado la televisión colombiana, imágenes que no ofrecen información sobre las causas de que los desplazados circulen y sean vistos en las ciudades colombianas grandes y en los municipios de las regiones ${ }^{8}$. 
El segundo lugar en cuanto al tipo de tópicos sobre el cual la mayoría de los niños demuestra un buen grado de conocimiento está constituido por "la cultura internacional popular" . ${ }^{9}$ Los nombres de deportistas, de "reality shows", y de presentadoras de TV son reconocidos por la mayoría. Se reitera la pista sugerida por una investigación anterior: la "información blanda" o "liviana" es el tipo de información con la cual casi todos los niños están familiarizados. Los futbolistas, pilotos de Fórmula 1, cantantes o héroes de los “realities" son imágenes puestas en circulación principalmente por la televisión en sus segmentos de farándula y deportes, y en los comerciales ${ }^{10}$.

En contraste, temas como la reelección del presidente colombiano Uribe, Osama Bin Laden y los "desplazados", acerca de los cuales se les preguntó a los escolares participantes, fueron evaluados como indicios acerca de si los niños han estado o no en contacto con las franjas de información de la oferta televisiva y de la prensa escrita, y a la vez si hablan sobre estos temas con los adultos o con sus profesores.

La familiaridad de los niños con la "información blanda o livia-

na” también se observa entre los escolares de capital escolar restringido de Bogotá, Guambía y Puerto Tejada en la fase 2 del trabajo de campo desarrollada durante 2007 - 2008. Incluso el caso de Hugo Chávez, presidente de Venezuela, puede incluirse dentro de la cultura "light": el tratamiento que los medios colombianos le han dado ha sido tan sensacionalista que su rostro y figura han tomado un carácter similar al que se le da a los personajes de la farándula y el entretenimiento: es reconocido por absolutamente todos los grupos, incluso los sectores populares rurales, tengan o no algún grado de cultura política. En contraste, no sucede lo mismo con el entonces vicepresidente colombiano Francisco Santos. Es una de las fotografías menos reconocidas, porque es un personaje del campo político nacional que no ha sido "construido" por la TV con los rasgos del sensacionalismo ${ }^{11}$. Las imágenes más identificadas en Bogotá, Guambía y Puerto Tejada coinciden con los personajes de los que más se estaba hablando en los medios de comunicación en el momento en que se aplicó la encuesta; incluso es el caso de Andrea Serna, la presentadora de TV con su programa El factor XS, concurso musical para niños. Se confirma lo citado arriba: Hugo Chávez es reconocido de manera exacta casi con el mismo porcentaje en los tres lugares citados, situación que no ocurre con ninguna otra de las imágenes o palabras sobre las cuales se preguntó a los niños.

Debe registrarse el contraste entre las respuestas sobre el reconocimiento de las letras "WWW", lo cual puede tomarse como un indicio acerca de la familiaridad de los niños con la red Internet: Saben a qué se refieren estas letras aproximadamente $70 \%$ de los niños de Bogotá. A pesar de pertenecer a sectores populares, el contexto urbano ofrece más ocasiones de contacto con las tecnologías o de alusión a ellas. En cambio los niños y niñas del pequeño municipio de Puerto Tejada (15\%) y los del pueblo guambiano (12\%) están mucho menos enterados acerca de Internet. Este tema se profundizará más adelante.

Retomando los resultados de la fase 1, en los grupos de capital escolar ampliado los niños demuestran un buen nivel de información acerca de lo que podemos llamar "temas de actualidad". Estos niños establecen una relación de mayor "cercanía" con la oferta de información de la TV. No es que les gusten los noticieros ni que ellos mismos los elijan cuando encienden el televisor. Los ven "de reojo" con sus padres, abuelos o tíos, sin atención concentrada. Lo que aquí pesa es la actitud familiar que se interesa por ciertos asuntos, los comenta, conversa sobre ellos y da sus juicios. Y en ese escenario hogareño el niño es influido por los intereses de los adultos, y por su percepción y valoraciones de algunos de los hechos que suceden en su localidad o en el país, o de los que presentan los géneros informativos. Otro factor o "mediación” que opera en este caso es la educación formal, pues lo visto y oído en casa entra en relación con el capital escolar acumulado. 
En los sectores populares la mayoría de los niños han declarado que no les gustan los noticieros porque les parecen "aburridos" y muy largos, y porque no les agradan las noticias sobre masacres y sobre desastres, algunas de las cuales les producen tristeza. El noticiero, entonces, aparece disociado de las características de la televisión de entretenimiento, y "localizado" en otra categoría: no sólo asocian este género con algo tedioso, sino que también lo relacionan con lo no placentero, y como fuente de hechos desagradables, por lo trágicos. Hay que resaltar, sin embargo, que los grupos urbanos de todos modos consideran "la información" o el "estar informado" como un valor deseable, y así lo declaran. Este ideal de la modernidad parece haber sido interiorizado por ellos.

En la fase 2 se obtuvieron los hallazgos que se registran en las páginas siguientes, con respecto a lo que les gusta y no les gusta a los niños de los noticieros. Al ser preguntados los niños qué les gusta, sus respuestas fueron agrupadas en cinco categorías, así: La primera es la de Características, de acuerdo a si les atribuyen a los noticieros determinada valoración, como "importantes", "interesantes" u otra. La segunda categoría es la de Componente o sección según hayan dicho que les interesa alguna parte especial del formato del noticiero. La tercera categoría es la de Tema, si los niños y niñas especifican qué tipo de noticias son las que más les interesan: "Noticias en general”, "locales", "nacionales", “internacionales”, “de accidentes”, "del conflicto armado”, "de desastres”, "de fallecimientos", “de historias de personas”, “económicas”, “esotéricas”. La cuarta categoría es la de Educación, que cubre los casos en los que los niños consideran que el noticiero les ofrece algún tipo de aprendizaje. La quinta categoría es la de Implicación, que abarca el grado de cercanía o relación que una noticia pueda tener con las vidas cotidianas de los niños espectadores, lo cual ya se abordó en el capítulo precedente.

En Bogotá y en Puerto Tejada para 56,1\% y 31,9\% de los niños entrevistados el elemento de los noticieros que más les interesa es la agenda de temas que las noticias abordan, enumerados en el párrafo anterior. En Bogotá les llama la atención las noticias de desastres y las internacionales (24,3\% cada una). En Puerto Tejada las noticias del conflicto armado, (33,3\%), seguidas de las noticias sobre accidentes y desastres (13,3\% cada una). En Guambía las del conflicto armado y las de desastres fueron citadas en igual proporción (33,3\%). Sin embargo hay que aclarar que a los niños les gustan las noticias sobre el conflicto solamente cuando hay informaciones positivas como la liberación de secuestrados. Se retomará este tema.

En Guambía el aspecto que más les llama la atención es determinado Componente o sección de los noticieros; 37,9\% de los niños entrevistados mencionaron la sección de deportes como la gran favorita. En Bogotá y Puerto Tejada, determinada Sección de los noticieros es el elemento que en segundo lugar dicen los niños que les interesa. La sección de deportes también es la que tiene mayor aceptación. A pesar de que la categoría Educación no registra porcentajes altos (10.6\% en Bogotá y $6.4 \%$ en Puerto Tejada), no deja de ser importante que algunos niños de las localidades urbanas encuentren en los noticieros la posibilidad de aprender algo, en algunos casos relacionado con su propio comportamiento, en otros con prevención de riesgos que pueden correr en su ciudad.

Finalmente, hay que decir que una alta proporción de niños en Guambía declaró que no sabe con exactitud qué es lo que más les gusta de los noticieros (44,8\%). Esto puede estar relacionado con el hecho de que la mayoría de estos niños y niñas no ven televisión con regularidad. El 48,4\% de ellos dicen que ven noticieros "a veces". Aunque esta cifra no se aleja mucho de las registradas en Bogotá y Puerto Tejada, en Guambía la mayoría de los niños no tiene televisor en su propia vivienda, sino que van a ver televisión donde vecinos o familiares. En consecuencia, la relación de estos niños con el televisor y con los noticieros no es frecuente, como en las otras dos ciudades citadas en este párrafo, donde se realizó la fase 2 del trabajo de campo. 


\section{Lo que les gusta a los niños de los noticieros, según la localidad donde viven}

\begin{tabular}{|lcc|c|}
\hline \multicolumn{1}{|c}{$\begin{array}{c}\text { Las cosas que les gustan a los niños de los } \\
\text { noticieros }\end{array}$} & \multicolumn{3}{c|}{ Porcentajes para cada localidad } \\
\cline { 2 - 4 } & Bogotá & Guambía & Puerto Tejada \\
\hline CARACTERISTICAS DE LOS NOTICIEROS & $\mathbf{7 , 6}$ & $\mathbf{0 , 0}$ & $\mathbf{4 , 3}$ \\
\hline Importantes & 60,0 & 0,0 & 100,0 \\
\hline Interesantes & 40,0 & 0,0 & 0,0 \\
\hline COMPONENTE O SECCIÓN & $\mathbf{1 5 , 2}$ & $\mathbf{3 7 , 9}$ & $\mathbf{2 3 , 4}$ \\
\hline Deportes & 40,0 & 81,8 & 81,8 \\
Entrevistas & 10,0 & 0,0 & 0,0 \\
Farándula y entretenimiento & 20,0 & 18,2 & 18,2 \\
Pronóstico del clima & 20,0 & 0,0 & 0,0 \\
Titulares & 10,0 & 0,0 & 0,0 \\
TEMA & $\mathbf{5 6 , 1}$ & $\mathbf{1 0 , 3}$ & $\mathbf{3 1 , 9}$ \\
Noticias locales & 8,1 & 0,0 & 0,0 \\
Noticias nacionales & 10,8 & 33,3 & 0,0 \\
Noticias internacionales & 24,3 & 0,0 & 6,7 \\
\hline Noticias de accidentes & 2,7 & 0,0 & 13,3 \\
Noticias del conflicto armado & 8,1 & 33,3 & 33,3 \\
Noticias de desastres & 24,3 & 33,3 & 13,3 \\
\hline Noticias de fallecimientos & 0,0 & 0,0 & 6,7 \\
\hline Noticias de historias de personas & 5,4 & 0,0 & 0,0 \\
\hline Noticias de temas positivos & 0,0 & 0,0 & 13,3 \\
\hline Noticias en general & 13,5 & 0,0 & 0,0 \\
\hline Noticias económicas & 0,0 & 0,0 & 6,7 \\
Noticias esotéricas & 2,7 & 0,0 & 6,7 \\
\hline EDUCACIÓN & $\mathbf{1 0 , 6}$ & $\mathbf{0 , 0}$ & $\mathbf{6 , 4}$ \\
\hline Educación - comportamiento & 42,9 & 0,0 & 33,3 \\
Educación - prevención & 42,9 & 0,0 & 33,3 \\
Educación en general & 14,3 & 0,0 & 33,3 \\
IMPLICACIÓN & $\mathbf{1 0 , 6}$ & $\mathbf{0 , 0}$ & $\mathbf{1 0 , 6}$ \\
NADA & $\mathbf{0 , 0}$ & $\mathbf{6 , 9}$ & $\mathbf{1 2 , 8}$ \\
NO SABE / NO RESPONDE & $\mathbf{0 , 0}$ & $\mathbf{4 4 , 8}$ & $\mathbf{1 0 , 6}$ \\
\hline
\end{tabular}

Al ser preguntados los niños qué no les gusta de los noticieros sus respuestas fueron agrupadas en 6 categorías: La primera es la de Características, de acuerdo a si les atribuyen a los noticieros determinada valoración. Se identificaron las siguientes: "Aburridos", "Extensos", "No tienen credibilidad", "Poco importantes", "Repetitivos", y se acuñó la categoría de "Condenan a protagonistas de la noticia” cuando los niños expresaron un juicio negativo sobre algún personaje. La segunda categoría es la de Componente o sección según hayan dicho que les disgusta alguna parte especial del formato del noticiero. La tercera categoría es la de Tema, si los niños y niñas especifican qué tipo de noticias son las que no les gustan, así: "Noticias de accidentes”, "del conflicto armado”, "de desastres”, "de fallecimientos”, "de manifestaciones públicas”, “de política”, "de robos”, "de violencia en general”, "de violencia-internacionales”, “judiciales”. La cuarta categoría es la de Identificación emocional, que cubre los casos en los que los niños consideran que las noticias afectan negativamente su estado de ánimo. La quinta categoría es la de Implicación, que abarca el grado de cercanía o relación que una noticia pueda tener con las vidas cotidianas de los niños espectadores.

A los niños encuestados en Bogotá lo que no les gusta de los noticieros son las características de estos programas (55,9\%). Para la mayoría de ellos los noticieros son aburridos $(68,4)$ y en menor grado extensos y repetitivos $(10,5 \%$ en cada caso). En cambio para los niños de Puerto Tejada determinados temas es lo que menos les gusta de los noticieros (49,0\%). Las noticias que causan más rechazo entre estos niños son las del conflicto armado (20,8\%), las de robos (16,7\%) y las de violencia en general (12,5\%). Aunque pareciera existir una contradicción entre estos niños con respecto a las noticias del conflicto armado pues ellas también aparecen como las que más les gustan (Ver cuadro) tal contradicción no se presenta, porque lo que realmente les gusta a estos niños no son las noticias sobre secuestros, sino las de la liberación de personas secuestradas. El énfasis de los niños de Puerto Tejada en este aspecto particular obedece a que en el momento en que se aplicó la encuesta en esta localidad se presentó la liberación por parte de las FARC de las políticas Clara Rojas y Consuelo González de Perdomo. ${ }^{12}$, un hecho que los noticieros cubrieron ampliamente. Las respuestas de estos niños a la pregunta “¿Qué no te gusta de los noticieros?” confirma justamente que lo que a ellos no les gusta de las noticias sobre secuestros es que este problema suceda en Colombia. 
Una situación similar se evidencia en Guambía. No sólo son determinados temas de las noticias lo que menos les gusta a estos niños de los noticieros, sino también determinados componentes o secciones de los mismos (20,7\% en cada caso). En relación con los temas, las noticias que menos les gustan son las del conflicto armado (33,3\%), las de accidentes, de desastres, de fallecimientos y las de violencia:

-No me gustan las noticias malas, de masacres. (Niño 12 años - Bogotá).

-Por las muertes, por los derrumbes, los huracanes, terremotos, porque de pronto viene un huracán para Bogotá. (Niño 9 años - Bogotá).

-Muy aburrido cuando hablan, cuando dicen que hay "hartos"muertos y cuando atropellan a alguien. (Niña 9 años - Bogotá).

- Cuando pasan noticias sobre casas dañadas con armas. ( Niño 8 añosGuambía).

-Las noticias de las inundaciones (Niño 11 años-Guambía)

En cuanto a las noticias sobre el conflicto armado, lo que específicamente no les gusta a los niños de Guambía de este tipo de noticias, son las acciones crueles.

En cuanto a la categoría de implicación sólo en Puerto Tejada aparecen registros de esta percepción de las noticias, con respuestas como las siguientes:

- ...matan muchos niños. Niños que salen con cuatro manos, niños que los ponen en la estufa... (Niño - 9 años).

- ...cuando violan a los niños... (Niña - 9 años).

Lo anterior sugiere que los niños se interesan por una noticia cuando esta involucra a otros niños y niñas, sus semejantes. Aunque las respuestas a la encuesta parecerían sugerir que este factor no es importante (sólo un 10\% lo mencionaron) el trabajo cualitativo de los talleres sí hizo visible que para ellos y ellas es importante el grado de implicación.

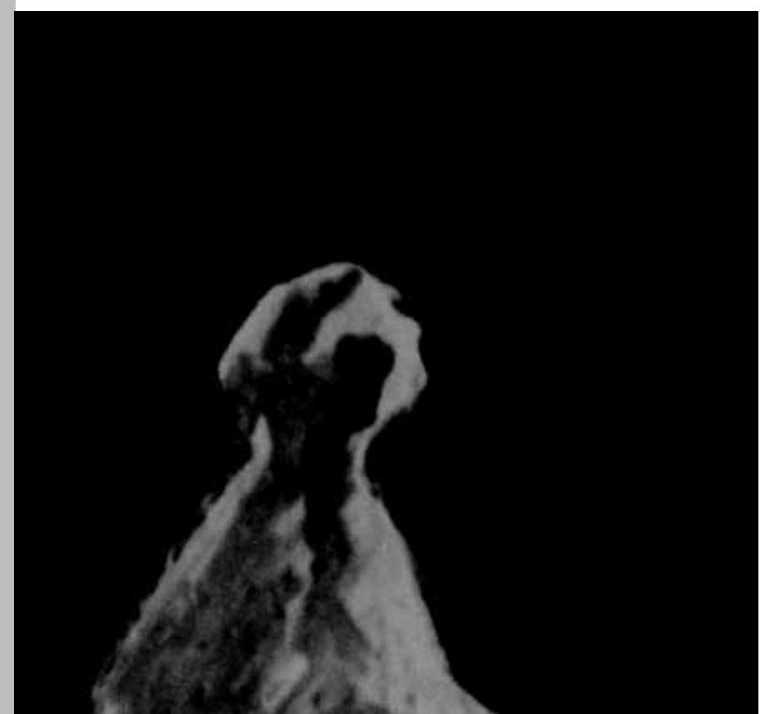

\section{La televisión sola no es buena informadora, ni transmisora de contenidos factuales.}

La pantalla televisiva no es eficaz en comunicar información, construir representaciones, formar valores o proponer modelos de comportamiento, si no ocurren simultáneamente otras mediaciones ejercidas por los pares en edad o los adultos con los cuales los niños interactúan. Un dato aparentemente contrario a lo que se acaba de señalar, es que los niños identifican a la televisión como la principal proveedora de sus conocimientos sobre la realidad, excepto en los grupos de capital escolar ampliado, en los cuales los padres superan a la TV como fuente de información. Es decir, ellos son nombrados con mayor frecuencia como los que ofrecen a los niños ideas y conocimientos sobre los temas consultados, aunque la televisión también es citada como referente importante.

Durante la fase 2 se preguntó a los niños de 3 localidades acerca de cuatro temas informativos, para saber qué conocimientos tienen los niños: "SIDA", "IVA" (impuesto a bienes de consumo), "Calentamiento global" y "Parapolítica". Este último es un término que alude a la infiltración de los paramilitares en las instituciones del estado colombiano incluido el Congreso, y se trata de una palabra que ha sido publicitada de manera frecuente en los noticieros y programas de opinión de la TV, y además en la radio y la prensa. Los niños y niñas de Puerto Tejada y Guambía no respondieron acerca del "Calentamiento global" ni de la "Parapolítica". O sea que no tienen conocimientos sobre estos hechos o palabras ${ }^{13}$. Entre las fuentes a través de las cuales los niños encuestados obtuvieron información acerca de la palabra SIDA, la televisión es el medio más nombrado en las tres localidades, principalmente en Guambía. No obstante, los profesores y los padres también son citados como emisores de información sobre este tema, pero con una enorme distancia de la TV. Al parecer, los padres y los profesores de Bogotá están más dispuestos a hablar sobre este tipo de temas que los de las otras dos localidades.

Es necesario destacar, en el caso de Guambía, la importancia de la radio como un medio a través del cual también se obtienen conocimientos sobre diferentes temas, como por ejemplo el SIDA. Nótese que los tres grupos de niños de sectores populares han nombrado la radio, y que - en contraste- no hay mención alguna de los periódicos. El análisis de los datos muestra que en el mundo infantil pesan mucho los adultos en cuanto a su influencia en la socialización de los menores. Tan sólo en Puerto Tejada los niños expresaron que saben acerca del SIDA "por sus amigos". En la mayoría de los casos priman los adultos. Más adelante en la adolescencia y juventud los pares en edad serán prioritarios como referentes, pero sobre todo en la etapa más temprana, aproximadamente hasta los 10 años, los padres y maestros son percibidos por los niños como muy importantes en sus funciones de "mediadores" de sus creencias, conocimientos, actitudes y valores, y así ellos y ellas lo expresan. 
Los niños de capital escolar ampliado dicen ver televisión en compañía de alguno de los padres o con los hermanos y hermanas. Sin embargo, la disponibilidad de un mayor número de aparatos de TV en el hogar, y la situación habitual de que el padre y la madre trabajan, hace más frecuente que los niños de sectores sociales altos vean más tiempo la televisión solos. En los sectores populares la situación más usual es la de ver televisión en compañía, pues la disponibilidad de aparatos receptores es menor, y a menudo conviven en grupos familiares más numerosos. En el caso de los niños rurales entrevistados, en Guambía en las fases 1 y 2 y en Zaragoza en la fase 1, a veces ven televisión o proyecciones de VHS o DVD en la vivienda de otra familia, puesto que disponer de un televisor por hogar no es lo común. Además, se recuerda que en 2004 cuando se hizo el trabajo de campo en Zaragoza fuimos informados acerca de que durante 2 años no habían tenido la señal de TV por haber sido destruida la antena transmisora.

La televisión es la principal fuente de información citada por una proporción alta de niños. Según ellos y ellas lo han afirmado, aprenden de la pequeña pantalla acerca de un rango amplio de temas. Puede que en realidad no sea la TV la que tiene el predominio, pero los niños y niñas así la perciben. Los padres son citados en segundo lugar, pero con bastante diferencia. Ya se aludió antes al tema del poco reconocimiento de los padres como proveedores de información, a excepción de las familias de capital escolar ampliado. Tanto padres como educadores se ocupan de manera selectiva de determinados temas, y descartan otros: por ejemplo, según los niños sobre el SIDA o el calentamiento global aprenden en el colegio o escuela más que en la familia. En relación con sucesos de actualidad del país o internacionales la escuela no es citada por los niños como proveedora de información. Tampoco la cultura "light", los realities o las vedettes deportivas se incluyen en los tópicos que aparecen dentro del tiempo y el espacio escolares.

Paradójicamente, aunque los niños de capital escolar ampliado pertenecen a instituciones que tienen estándares de calidad educativa superiores a los planteles de los otros niños participantes, estos niños escasamente han señalado a los profesores y al colegio como las principales fuentes de lo que saben sobre la mayoría de los temas consultados ${ }^{14}$. Hay que señalar una particularidad del mundo rural: los niños mencionan "la gente dice" o "todo el mundo dice", expresiones que, en este contexto, equivalen al peso que en la construcción de significados toma la comunidad relativamente pequeña de la cual hacen parte, y las culturas orales.
La información reunida y analizada sugiere que es menor la i nfluencia de los medios entre mayor es la "mediación" de los padres o adultos que rodean al niño, y del sistema escolar. Es decir, estas dos últimas agencias disminuyen el influjo de los medios cuando actúan como instancias fuertes que proveen de conocimiento y argumentos a los niños sobre determinados

temas. En el caso de los niños de capital escolar ampliado, la información de los medios -aunque esquemática y deficiente- cae en terreno fértil para que a partir de unas pocas pistas alusivas a una u otra situación, los niños establezcan algún tipo de intertextualidad con lo que conversan y aprenden con los adultos, y también con lo que leen y se instruyen en el sistema escolar. De tal modo que esos "mínimos" que pone en circulación el sistema convencional y comercial de medios e información -que es el que la mayoría de familias ven- "se crucen" en alguna medida con otros conocimientos y "textos", y se propicien así reelaboraciones más complejas de lo que los medios ofrecen.

De lo anterior se deduce que son necesarias las "mediaciones" de los adultos del grupo familiar, y de los educadores, para activar el potencial formativo o instruccional de la televisión y de otros medios. Los cuales -por sí solos- no son eficaces en propiciar determinados tipos de aprendizaje. Nótese que se hace referencia a cuatro mediaciones: el acervo de conocimientos de la familia, junto con la acción socializadora que ella realiza; y el capital escolar que ofrece al niño la institución educativa, junto con la acción de enseñanza que esta ejerce. Es decir, que lo que pesa aquí son las interacciones interpersonales. No basta el mero capital escolar que tanto la familia como la escuela hayan acumulado. Es oportuno reiterar ahora que los niños reconocen a los adultos como interlocutores importantes en sus procesos de aprender sobre el mundo que los rodea. Para que los medios actualicen su potencial instructivo o formativo deben ocurrir procesos de comunicación intersubjetiva: conversaciones e interacciones entre niños y adultos, y entre pares en edad. Esto parece indicar que los procedimientos del diálogo y la expresión oral serían elementos esenciales de una pedagógía orientada a activar el potencial de conocimientos de los niños y niñas a través de ver con ellos los noticieros, y otros géneros de los cuales puedan derivarse aprendizajes intelectivos y también emocionales. 


\section{Todos los niños no consumen la misma "dieta" diaria de TV: El "capital escolar" corresponde a patrones diferenciados de consumo de medios.}

La “mediación” o variable a la cual hemos dedicado especial atención es el capital escolar del niño, asociado a su historia familiar. Hay evidencia de un mejor nivel de información sobre asuntos de actualidad, mayores conocimientos sobre temas relacionados con el país, y mejores competencias lógicas y lingüísticas en niños de capital escolar ampliado. Sin embargo, también tiene que considerarse, en la adquisición de capital escolar, la "cuota" que corresponde tanto a la televisión como a los computadores y a Internet, y la acción que pueden haber tenido estos medios en la activación de habilidades cognitivas en este grupo particular de niños y niñas, gracias también a que el "menú" especial de medios audiovisuales transnacionales de los que se nutren, (series y películas extranjeras, a menudo filmes en inglés o francés, y en general programas en formatos estéticamente más complejos) no es equiparable a la dieta de telenovelas o películas de acción de los sectores populares.

La televisión sigue siendo la tecnología que copa una proporción más alta del tiempo de los niños hasta aproximadamente los 12 años, comparada con el Internet o los videojuegos. La disponibilidad de televisores va de un promedio de tres aparatos en los hogares de clase social superior, a la no existencia de un televisor por familia en el mundo rural. La TV la nombran los niños como proveedora de las imágenes y discursos sobre la realidad en mucha mayor medida que a los otros medios de comunicación. En segundo lugar aparece la radio, pero sólo es citada por los niños de sectores populares, y por los rurales. En los hogares de los niños de capital escolar ampliado existen reglas claras que fijan límites fuertes al número de horas dedicadas a la televisión. El número promedio de programas que estos niños ven al día es de 3, o sea aproximadamente hora y media de televidencia. En contraste con el grupo de capital escolar restringido, donde se registran consumos de 6 o 7 programas, es decir más de 3 horas de televisión diarias. Las telenovelas están prohibidas explícitamente en algunos hogares de capital escolar ampliado, y en algunos casos también los programas de contenidos violentos.
Durante las entrevistas los escolares de capital escolar ampliado afirman ver los noticieros de las cadenas comerciales colombianas, y también nombran a CNN. Ya se explicó antes que aún en los sectores sociales altos de cultura ilustrada los niños y niñas ven noticieros de manera más bien desatenta e inconstante. La información que adquieren y organizan mentalmente debe adjudicarse más que a la televidencia del noticiero a los intercambios lingüísticos con sus padres o con los adultos del grupo familiar. Se trata de niños con excelentes competencias de lecto-escritura, quienes leen regularmente, y por ende están dotados de buenas competencias lógicas y lingüísticas.

Así mismo, se trata de niños estimulados por las conversaciones dentro de su misma familia en cuanto a los temas relativos a los hechos político-sociales del país y del mundo.

Otro dato clave es que en los grupos de capital escolar ampliado aparece la prensa como fuente de información, especialmente alrededor de los temas del conflicto armado colombiano, la reelección presidencial de Uribe en Colombia durante la fase 1 del trabajo de campo, y la información internacional. Los niños de este grupo mencionan los periódicos. La disponibilidad de material impreso en los hogares de capital escolar ampliado, y el participar así sea parcialmente en las prácticas de lectura del periódico de los adultos, incide en las modalidades y frecuencias con las que los niños puedan recurrir a la prensa escrita y a la lectura de impresos como fuentes de información. En contraste con lo anterior, los niños de capital escolar restringido y de sectores populares de Cali se refieren a los periódicos El caleño y Q'hubo, es decir, a la prensa popular. También nombran a la radio, y así mismo lo hacen los niños rurales. Pero este último es un medio con el que los niños de capital escolar ampliado tienen poco contacto, a no ser para escuchar música.

Los niños de capital escolar restringido no parecen tener el hábito de ver el noticiero de televisión. Ya se ha dicho que los de Zaragoza, el pequeño poblado de afrodescendientes, en la fase 1 del trabajo de campo (2004-2005) no habían tenido señal de TV por 2 años. Es una de las razones por las cuales este grupo no demostró información sobre tópicos que en su momento fueron mostrados por la televisión recurrentemente, tales como la reelección del presidente, la figura de Osama Bin Laden, y ni siquiera el reality de CaracolTV Desafío 20-04. En cuanto a los niños de Guambía no disponen de un televisor en cada vivienda. Durante la fase 1 también evidenciaron escasos conocimientos de la información que circula por TV. Su relativo aislamiento -tanto geográfico como cultural- como grupo étnico con características y prácticas singulares es una condición que marca su desconocimiento de algunos asuntos del orden nacional e internacional, rasgo que se comprobó a través de varias actividades durante el trabajo de campo. En resumen, en el caso de los dos grupos de niños rurales que participaron en el trabajo de campo durante la fase 1 se registró que la influencia de los medios en sus representaciones sociales y en su percepción de la realidad era relativa. 
En la fase 2 (2007 - 2008), la relación de los niños de Guambía con la televisión seguía siendo poco frecuente, por razones que ya se han explicado: de 31 hogares entrevistados solo 17 tenían un televisor en su casa. Por otra parte, aunque un poco más de la mitad del grupo encuestado disponía del aparato receptor, la mayoría de ellos afirmaron no ver televisión todos los días $(83,9 \%)$.

Las razones por las cuales no ven televisión con tanta frecuencia las explican así:

- En la casa colaboro bastante y sólo veo a veces en las noches. (Niño, 10 años).

- No veo televisión porque mi mamá no me deja, ella me dice que tengo que estudiar. (Niña, 9 años)

- Porque no quiero ver, porque salen malas películas. (Niño, 8 años).

- No veo televisión todos los días porque hago tareas y leo cartillas Nacho. (Niña, 8 años).

- Porque mi papá me dice que estudie. (Niña, 9 años).

- No me gusta ver televisión. (Niña, 8 años).

- Mis papás me dicen que vea poco porque se me dañan los ojos. (Niño, 8 años).

- Porque a veces presentan cosas feas. (Niño, 11 años)

La televisión no parece deslumbrar a los pequeños guambianos que aún asisten a la escuela primaria. Quizá por los días más cortos en los hábitos de familias agricultoras -levantada y dormida temprano-,y porque las familias pasan más tiempo al aire libre. Pero, más significativo aún, puede ser que los niños y niñas de este pueblo indígena intuitivamente no sientan afinidad o no encuentren placer en el flujo de situaciones, gustos, imágenes y diálogos que la TV les lleva, ya que los contenidos de "la caja" pueden resultar bastante discordantes en el medio ambiental y cultural donde habitan.

En la fase 2 de la investigación las principales variables tenidas en cuenta fueron ubicación geográfica, nivel socioeconómico, capital escolar, etnia, y género. Estas "mediaciones" ejercen su influencia a la hora de analizar la frecuencia con la que los niños ven noticieros. Se debe recordar que en la fase 2 participaron solamente niños de sectores populares.

En general, la mayoría de los niños y niñas entrevistados en las fases 1 y 2 no ven noticieros con frecuencia, como se señaló al comienzo. No obstante, la mayor o menor regularidad con la que ellos y ellas ven noticieros parece estar determinada por el capital escolar y por el nivel socioeconómico, pero también por el lugar geográfico donde viven (urbano/rural). Los niños de Bogotá, aún siendo de sectores pobres y de capital escolar restringido presentan una mayor exposición a los géneros informativos, si se comparan con los otros niños populares de Puerto Tejada y Guambía. En relación con la segunda variable, se puede establecer una asociación a manera de hipótesis, entre la existencia de una situación socioeconómica precaria y una menor exposición de los niños a los géneros informativos. Por ejemplo, en el caso de Puerto Tejada las condiciones socioeconómicas y el nivel de vida de los niños encuestados en esta localidad son notablemente inferiores con respecto a las de los niños encuestados en Bogotá.

La variable "etnia" tiene qué ponerse en cuestión, y atender más bien al grado de politización/despolitización del grupo de Puerto Tejada y del grupo de Guambía, más que a características culturales específicas. Los niños de Guambía pueden tener más interés en los géneros informativos gracias a sus relaciones cercanas con los procesos e instancias de toma de decisiones dentro de su comunidad indígena, ya que tanto las autoridades indígenas como el lugar donde está situado el Cabildo están localizados en su ámbito cotidiano inmediato. Puede entonces especularse acerca de que tengan un grado mayor de socialización en los asuntos públicos que los niños de Puerto Tejada que participaron en la fase 2 del trabajo de campo.

Se revisan a continuación los datos acerca de la televidencia de noticieros en los grupos de niños populares participantes. La mayoría de estos niños ven los noticieros de los canales privados nacionales, es decir, Caracol y RCN. Caracol noticias tiene una mayor aceptación entre los niños de Bogotá y sobre todo entre los de Guambía. Mientras que los niños de Puerto Tejada prefieren ver Noticias RCN. No obstante, en este caso la diferencia entre ambos noticieros no es significativa. En contraste, sí es importante destacar la preferencia por los noticieros locales que se da principalmente en Bogotá, en el caso de City noticias.

También hubo mención en Puerto Tejada de los noticieros del canal regional más cercano, Telepacífico, transmitidos desde Cali, que son 90 minutos y Noti 5. Los niños de Guambía no mencionaron ningún noticiero local, hecho que requeriría explorar otros aspectos como el medio a través del cual reciben la señal de televisión, pues la ausencia de otras opciones explica que sólo ven los noticieros nacionales de las cadenas comerciales.

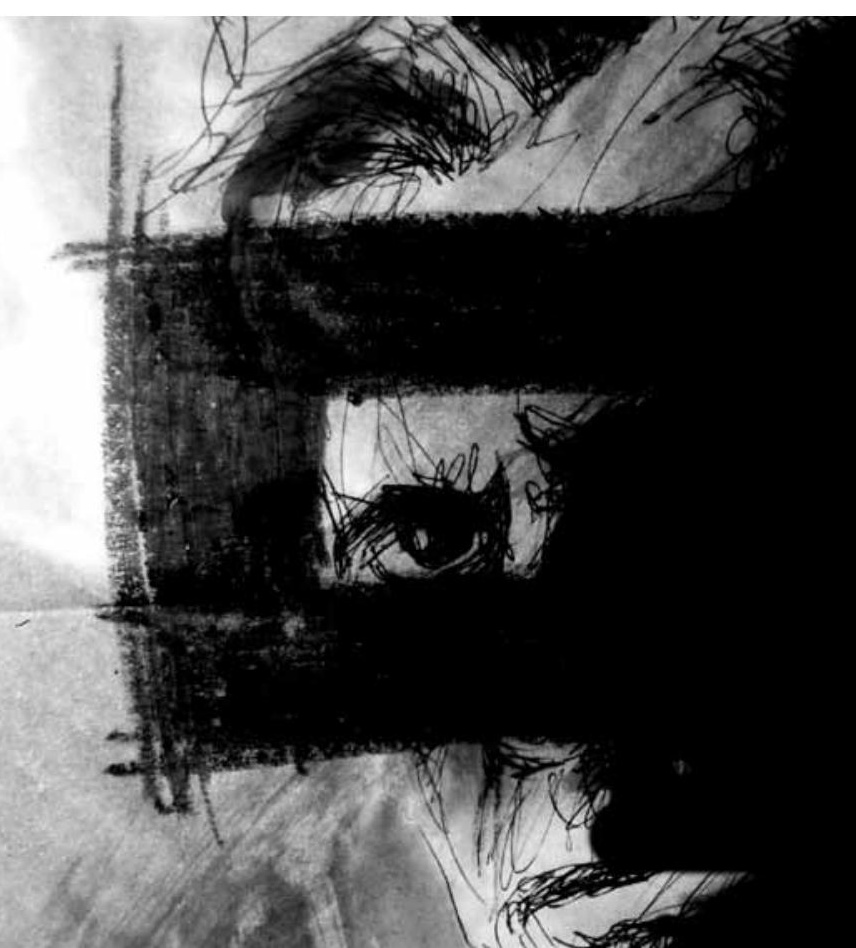




\section{Aprendizajes triviales y déficit de información}

Los géneros que los niños de capital escolar restringido consumen (dibujos animados, telenovelas, series y películas de acción) hacen que la televisión que ellos ven sea una "agencia" con efectos limitados en cuanto a los aprendizajes que pueden desarrollar, y al tipo de información que reciben. Por lo tanto, se retoma aquí al argumento de la crítica cultural argentina Beatriz Sarlo, cuando se pregunta si Mickey Mouse y los video juegos es el equipamiento cultural que los niños necesitan para situarse y desempeñarse en las sociedades latinoamericanas contemporáneas, desiguales, competitivas, y donde quienes toman las decisiones que afectan los intereses colectivos han sido entrenados en saberes "duros" como la economía, las finanzas, la electrónica o la investigación científica. ${ }^{15}$ Muniz Sodré ha planteado que la televisión comercial, con su abundancia de contenidos populares, tiene una especie de "contrato de lectura" con los estratos económicamente inferiores de la sociedad. ${ }^{16}$ Debe hacerse la precisión de que no se trata únicamente de escaso capital económico sino de la precariedad de capital escolar, y de la no familiaridad con bienes culturales diferentes de los de "la cultura internacional popular" sobre la que ha escrito el investigador Renato Ortiz. ${ }^{17}$ En la fase 2 de la investigación realizada en el período 2007 - 2008, la cual involucró solamente a escolares de sectores populares, los géneros televisivos que consumen estos niños tampoco les aportan saberes "duros", insumo que sería muy importante para la comprensión de la realidad social que viven y para poder intervenir en su transformación.

La oferta de canales y programas de televisión disponibles para la audiencia infantil determina en alguna medida los tipos de programas que ven los niños. Por ejemplo, los géneros preferidos por los niños y las niñas de Bogotá y Puerto Tejada presentan una mayor diversidad en relación con los géneros de los programas que más les gustan a los niños de Guambía. Si se observan los canales en donde se transmiten los programas favoritos de los niños de estas tres localidades, los de Bogotá y Puerto Tejada cuentan con una oferta de canales mucho más amplia y variada que los de Guambía. Hay que tener en cuenta, además, que los de Bogotá disponen de más canales locales, como City TV y el Canal Capital.

Ahora bien, el tipo de programas que más les gusta ver a los niños y niñas no sólo depende de la oferta de canales y programas de televisión, sino también del grado de urbanización del lugar donde han sido socializados y residen, del nivel socioeconómico, y del capital escolar. Esta relación se observa de manera más clara comparando a Bogotá y Puerto Tejada. Aunque ambas localidades cuentan con mayor número de canales de TV en oferta, las elecciones de programas por los niños y niñas son sociológicamente diferenciadas. Teniendo en cuenta los programas que más menciones registraron, se puede ver que los géneros favoritos de los niños de Bogotá (60 niños encuestados) son mucho más variados que los géneros de los programas que prefieren los niños de Puerto Tejada. En el caso de Bogotá, eligen los dibujos animados (30 menciones) por encima de las novelas (19 menciones). Llama la atención la presencia, únicamente en Bogotá, de los noticieros como programas favoritos (9 menciones). Les siguen los “contenedores" infantiles (6 menciones), programas de acción (5 menciones), comedia mexicana (5 menciones) y educativo ( 3 menciones $)^{18}$. 
Por el contrario, entre los niños de Puerto Tejada (un total de 39) resultan ser las novelas (19 menciones) los programas que más les gustan. Los dibujos animados sólo registran 5 menciones y los programas de acción también 5 menciones. Con respecto al resguardo indígena de Guambía (de un total de 31 niños ) los programas de televisión favoritos son las novelas (18 menciones) y los dibujos animados (11 menciones). Esta tendencia se explica por la oferta limitada de TV que tienen, únicamente los dos canales comerciales nacionales de televisión, en los cuales de lunes a viernes son precisamente las novelas las que ocupan la mayor parte de la programación.

Después de presentar la "dieta" de programas televisivos que los niños más consumen podemos volver a la idea de su escaso interés por los géneros noticiosos, que se evidencia en el desconocimiento de los temas específicos acerca de los cuales la fase 2007-2008 consultó, temas que las noticias abordan recurrentemente. A continuación retomamos en detalle este aspecto: el desconocimiento casi total de los niños guambianos y afrodescendientes del significado de algunas palabras, unas con amplia circulación en los medios, y otras que ya forman parte de la vida cotidiana, lo cual contrasta con el conocimiento que de ellas tienen los niños participantes de Bogotá.

Frente a la pregunta “¿Qué sabes de la palabra SIDA?” las respuestas de los niños aluden siempre a dos aspectos: el SIDA como enfermedad y las formas de trasmisión. El grado de urbanización determina qué tanto saben los niños sobre esta enfermedad. Los niños de Guambía y Puerto Tejada son quienes menos conocimientos tienen acerca del SIDA. Por otra parte, aunque en las tres localidades los niños generalmente definen el SIDA simplemente como una enfermedad, los de Bogotá y Puerto Tejada son los que más nombran algunas de las características que popularmente se han asociado con este problema, unas ciertas y otras falsas. Por ejemplo, que es una enfermedad contagiosa, que produce la muerte, que está relacionada con ciertas ocupaciones como la prostitución, que es peligrosa, o que es propia de determinado género, especialmente del masculino. Asimismo, sólo los niños de Bogotá y Puerto Tejada hacen referencia a las formas de transmisión de esta enfermedad, especialmente a las relaciones sexuales.

La mayoría de los niños encuestados en Bogotá (85\%) y Puerto Tejada (94\%) y la totalidad de los niños encuestados en Guambía, no saben qué es el I.V.A., un impuesto al consumo, que grava determinados bienes. Sin embargo, a mayor nivel de urbanización existen más posibilidades de que los niños tengan alguna idea cercana a lo que significa esta palabra. Sólo en Bogotá y en Puerto Tejada aparecen niños que lograron relacionar esta palabra con el concepto de impuesto. Es importante registrar el desconocimiento de un término que se refiere a los impuestos que se aplican a un conjunto grande de bienes de consumo generalizado, desde algunos que hacen parte de la llamada "canasta familiar", o sea los bienes básicos de subsistencia como los alimentos. Es significativo el desconocimiento de un factor que afecta la vida de todos los colombianos, y de manera más intensa a los sectores pobres.

La mayoría de los niños encuestados en Bogotá y la totalidad de los niños encuestados en Puerto Tejada y en Guambía no saben qué es o a qué se refiere el “calentamiento global”. Sólo el 23,4\% de los niños encuestados en Bogotá dieron definiciones muy cercanas, por lo menos en la mayoría de los casos. El 10,0\% de estos niños relacionan las palabras calentamiento global con el calentamiento de la tierra, el 3,4\% hacen referencia a los efectos del calentamiento global como son el cambio climático y el deterioro ambiental. Sólo el 1,7\% mencionan cómo se produce el calentamiento global, es decir, que señalan el efecto invernadero como causa de este fenómeno. 
En cuanto al debate sobre "cultura light" versus "información”, se sintetizan en seguida planteamientos relacionados con estos dos tipos de oferta cultural. Existen dos aprendizajes diferenciados que promueven la escuela por una parte, y la televisión por otra. Jesús Martín Barbero ha formulado que la televisión de entretenimiento, al igual que otros medios electrónicos, no está afiliada al proyecto iluminista que caracteriza el canon escolar basado en la razón, y el aprendizaje lineal por etapas. ${ }^{19}$ Haciendo consideraciones semejantes, Valerio Fuenzalida, investigador y productor de la televisión chilena, ha argumentado acerca de las limitaciones de la TV, con su estética de magazín, para comunicar contenidos "duros" o "serios". Ha elogiado, en contraste, las bondades del lenguaje televisivo para proveer a los niños y adolescentes de satisfacción emocional, y de habilidades utilizables en su vida cotidiana: como por ejemplo aportarles modelos para sus relaciones interpersonales con los pares en edad o con los adultos. ${ }^{20}$

La preferencia de los niños por los programas que podemos adjetivar como "triviales”, por ejemplo los dibujos animados o las telenovelas se explica, según Fuenzalida ${ }^{21}$, porque el hogar y la escuela conllevan situaciones de vida y estados de ánimo muy distintos. En la escuela el niño está dispuesto a recibir los contenidos escolares racionalistas y metódicos. Por el contrario, cuando vuelve a casa el niño experimenta la necesidad de descansar y de re-energizarse, y para lograrlo busca en la televisión programas de entretenimiento que le permitan hacerlo.

Respecto al elogio de Fuenzalida sobre lo valioso de los aprendizajes que los niños obtendrían de la televisión de entretenimiento tendríamos que estar atentos a apreciar qué proporción de estas “enseñanzas para la vida” equivale a la reproducción de valores y modelos sociales convencionales, y a patrones estereotipados de identidad y de actuación social, cuando las niñas toman como ejemplos a las jóvenes actrices de TV o a las Barbies, y los niños adoptan las expectativas de llegar a ser hombres sexual y profesionalmente "exitosos”, con cuerpos que se acomoden a los estándares de la publicidad, amigas estilo "top model”, y suficiente dinero para gastar. ${ }^{22}$

\section{Niños sometidos a exclusión social y simbólica: \\ los afrodescendientes urbanos y rurales, y los niños de pueblos indígenas}

Los niños afrodescendientes urbanos y rurales, y los niños de pueblos indígenas dan evidencia de poseer menor capital escolar. Las dos fases del trabajo de campo consultaron 3 grupos de niños afrocolombianos: de Cali (Departamento del Valle del Cauca), afrodescendientes rurales del pequeño poblado de Zaragoza, (Departamento de Valle también), y niños afrodescendientes del municipio de Puerto Tejada (Departamento del Cauca). En cuanto a los niños indígenas, se involucraron dos grupos diferentes de niños y niñas de la comunidad guambiana (Departamento del Cauca). Todos los grupos nombrados han mostrado un bajo nivel de conocimientos dentro del área denominada "información”. Además, débiles competencias lógicas y lingüísticas y deficiencias de lecto-escritura. Los anteriores datos son indicadores de las circunstancias de discriminación que las comunidades afrodescendientes e indígenas han soportado en Colombia y América Latina históricamente. Pero también evidencian las condiciones de exclusión actual a las que siguen siendo sometidas: no tienen acceso a educación de calidad, ni oportunidades de mejorar su capital escolar, aún en las áreas urbanas como Cali, ciudad que tiene el mayor número de afrodescendientes del país. ${ }^{23}$

En Colombia desde los años 70 y 80 se hicieron más visibles en la esfera pública los debates sobre los temas étnicos y raciales, a la par que se fortalecieron las luchas políticas correspondientes. Fueron liderados por indígenas y negros, apoyados por organizaciones no gubernamentales, y por algunos académicos y políticos, quienes encontraron en la Constituyente y en la Constitución Política de 1991, la oportunidad para que el estado colombiano reconociera el carácter pluriétnico y multicultural de la nación. Este fue uno de los hechos que cuestionó la idea y el proyecto político de nación mestiza y homogénea, que habían sido sustentados por la élite blanca y criolla desde la Colonia. Muchos líderes de movimientos sociales étnicos, académicos y políticos han manifestado la necesidad de asumir una postura de estado multicultural y la ejecución de políticas de acción positiva, para los grupos étnicos raciales que se encuentran en situación de desventaja. 


\section{Los usos de las tecnologías de la comunicación}

En 2005 fue evidente que para los niños rurales -pueblo indígena de Guambía y afrocolombianos del poblado de Zaragoza- era desconocido el conjunto de letras "WWW" que sí identificaron con Internet casi la totalidad de los niños urbanos de Cali. La disponibilidad de las tecnologías para los escolares de primaria en sectores rurales o en sectores pobres de los municipios pequeños solo se ha modificado levemente con la introducción gubernamental de programas de instalación de computadores como COMPARTEL y "Computadores para educar" (CPE), que llegan a un número limitado de municipios y poblados de todos los “departamentos" en los que está dividido el país para su administración política. El segundo programa, CPE, cubre una proporción de escuelas públicas. ${ }^{25}$ Según la "Encuesta continua de hogares" del Departamento Administrativo Nacional de Estadística DANE de marzo 2009 la tenencia de computador en el hogar a nivel nacional pasó de $11.2 \%$ en 2003 a $22.8 \%$ en 2008, y únicamente $12.8 \%$ de los mismos grupos familiares consultados tienen acceso a Internet. ${ }^{26}$

En consecuencia, no es despreciable comparar los deseos con las oportunidades: en la comunidad guambiana fue entrevistada una familia que vive en el casco urbano del municipio de Silvia que, en el año 2005, había matriculado los tres niños de 15, 9 y 7 años en clases semanales de informática. La reflexión pertinente es que estos conocimientos se identifican como un bien cultural del que hay que disponer, tanto en los grupos familiares

La legitimación de determinadas normas no necesariamente se traduce a un tratamiento igual que la sociedad dé a los afrodescendientes y a los pueblos indígenas. Se precisan por lo tanto cambios culturales equivalentes a la legislación, que modifiquen tanto las percepciones de estos grupos como subalternos, así como también las interacciones de los otros grupos sociales con ellos. Igualmente se requieren políticas económicas, educativas y culturales que posibiliten la inclusión de los grupos étnicos a los derechos y bienes a los cuales son acreedores. Por otra parte, hay que citar que los gobiernos de 1991 en adelante no han cumplido con la reglamentación de las normas expedidas por la Constitución, las cuales debían garantizar, entre otros, la entrega de tierras a los grupos aludidos. Las enormes marchas indígenas nacionales que se han sucedido en los últimos años son mecanismos de movilización social para el reclamo de derechos no cumplidos por el estado colombiano. ${ }^{24}$

Lo pertinente para este estudio ha sido explorar cómo "leen" los diversos grupos étnicos la realidad colombiana, cómo se posicionan respecto a la construcción social de la realidad que la televisión u otros medios hacen, cómo se definen -ellos mismos y el lugar social que ocupan- en "la nación" colombiana, y si es posible rastrear particularidades en sus lecturas del mundo social. de áreas rurales o de municipios pequeños, como en los de las ciudades más pobladas y con mejor infraestructura de servicios. Puede que la mayoría de familias citadinas nunca vaya al teatro ni los niños hayan leído un solo relato de la rica literatura latinoamericana del siglo XX, o de las historias escritas y editadas especialmente para lectores infantiles; pero una alta proporción de padres hoy incluye el computador y otras tecnologías complementarias en la lista de competencias que deben cultivar sus hijos. El computador es valorado por los padres y madres de sectores medios y altos, principalmente en los ámbitos urbanos, así ellos y ellas tengan escaso capital escolar. Y también es valorado por algunas familias de sectores populares, que no obstante sus bajos ingresos económicos han acumulado un determinado grado de capital escolar y cultural. El computador es depositario hoy de una esperanza para el futuro. Las familias lo consideran como un factor clave que contribuye a la adquisición de competencias para sus hijos. Se volverá a este tema.

Las diferencias entre niños urbanos y rurales con respecto a identificar las letras "WWW" con el acceso a páginas web en Internet también volvieron a ser identificadas en la fase 2 de la investigación realizada entre 2007 y 2008 en la que solo participaron niños de sectores populares. Mientras el 66,7\% de los escolares encuestados en Bogotá asociaron las letras "WWW" con Internet, sólo el 15,4\% y el 12,9\% de los niños encuestados 
en Puerto Tejada y Guambía -respectivamente- lograron establecer esta relación. En 2008 el trabajo de campo en Guambía se realizó en la Concentración Escolar Las Delicias, institución educativa que hace parte del sistema de educación bilingüe de la propia comunidad, aunque es financiado por el estado. La escuela tiene una sala especial con 13 computadores vinculados a un servidor, para ser usados por los estudiantes de los grados 4 y $5 .{ }^{27}$ A través de la empresa del estado COMPARTEL está dotada del servicio de Internet banda ancha. Pero aunque la mayoría de niños de sectores sociales subalternos -tanto los del campo como los de la ciudad- no tienen acceso a un computador, la aspiración a dominar las competencias informáticas, y a usar esas tecnologías de todas maneras hace parte de sus aspiraciones. Varios pequeños pertenecientes a los pueblos indígenas Nasa, de la localidad de Toribío -suroccidente de Colombia- fueron entrevistados en abril de 2005 por un periodista de un programa documental de la televisión. Al preguntarles qué querían ser cuando grandes le respondieron "Manejar computador". ${ }^{28}$

Para los niños contemporáneos el acceso a un capital escolar mayor depende de su disponibilidad de un computador durante un número relativamente grande de horas a la semana, lo cual equivale casi siempre a que es necesario tenerlo en casa, pues los planteles que poseen computadores los prestan a los alumnos en horarios restringidos y para usos escolares específicos determinados por los profesores. Claro que no es desestimable la enorme oferta de pequeñas salas privadas de Internet en Colombia, desde las lujosas y sofisticadas de las ciudades llamadas "Café Internet", hasta sus imitaciones pobres pero que sin embargo proliferan en las calles de la mayoría de municipios pequeños, y en los terminales de buses de las ciudades, y a las cuales acceden, por un precio módico por hora o fracción de hora, prioritariamente los adolescentes de sectores populares.

Se debe tener en cuenta, eso sí, que los usos del PC varían, de manera similar a lo que se ha explicado respecto al consumo de productos de otros medios. Mientras una mayoría de niños con capital escolar restringido pasan el tiempo chateando, disfrutando con los videojuegos o bajando música, una proporción de los de capital escolar ampliado aunque chateen y vean videos comunes también dedicarán considerable tiempo a autoadiestrarse en las competencias informáticas más complejas, investigar para las tareas que el colegio exige, practicar los aprendizajes del lenguaje html en el diseño de páginas web o presentaciones en power point, utilizar software especializado para hacer composiciones musicales, o seguir un curso interactivo de una segunda lengua a través de la web. A esto hay que agregar que las familias que tienen un proyecto educativo explícito y fuerte para sus hijos a menudo ejercen una supervisión parental tanto del tiempo que los niños pasan en el computador, como del tipo de actividades en las que se involucran.
En cuanto a la gama de medios con los que tienen contacto los niños en el rango de edad de 8 a 10 años, el televisor sigue siendo el que ocupa la mayor parte de su tiempo. El computador va ganando adeptos a medida que crecen en edad, como se comprobó con los escolares de 10 a 12 años de Bogotá, aún siendo estos niños de estratos 1, 2 y 3 . El trabajo de campo realizado constata que en Colombia el computador e Internet constituyen ahora dispositivos ya incorporados a las rutinas semanales de los niños de sectores medios y altos, y que irán ganando horas de dedicación entre mayores se hagan. Ya se destacó que el computador es considerado por los padres de estos sectores sociales como un factor clave que contribuye a la adquisición de competencias escolares y culturales para sus hijos, y también como una ventaja para cuando estos entren al mercado laboral. Los aprendizajes en informática permiten beneficiarse de las redes en las cuales circula el conocimiento, y desempeñar trabajos "inteligentes". ${ }^{29}$ El mundo de los negocios exige hoy el cambio de métodos empresariales, y por lo tanto de patrones renovados de cualificación profesional. ${ }^{30}$ Desde otra perspectiva, la investigación y la práctica científicas también requieren de aprendizajes en las nuevas tecnologías electrónicas.

Sin embargo, en el continente latinoamericano donde tan sólo un tercio de los estudiantes que empiezan escuela primaria terminan la secundaria, no es la ciencia el ideal que orienta el interés generalizado que demuestran las clases medias y altas por los computadores y las tecnologías. Más bien sus expectativas se dirigen hacia la meta de que sus hijos sean competitivos a la hora de buscar un empleo, y también que exhiban el prestigio simbólico que otorga, desde temprana edad, el mostrar destrezas tecnológicas en varios espacios de la vida cotidiana, el colegio en la época de la primaria o la empresa a la cual llegue el recién graduado universitario ${ }^{31}$. Las tecnologías de la comunicación, en la medida en que son fuentes de información, herramientas de aprendizaje, y además, generadoras tanto de prestigio simbólico como de vínculos sociales, han adquirido un estatus de necesidades básicas en la canasta familiar de las clases medias y altas, y -al mismo tiempo- son indicadoras de la exclusión social a la que son sometidos vastos sectores de la población en Colombia. 


\section{El género como mediador de los usos del tiempo libre, y de los tipos de programa que el niño o niña consumen.}

No podría terminarse esta parte relativa a las relaciones de los niños con la televisión, sin hacer alusión al hecho de que hombres y mujeres se comportan distinto a la hora de elegir los programas que quieren ver. Los niños gustan más de los dibujos animados y series o películas de acción. Las niñas expresan su favoritismo por las telenovelas, principalmente las transmitidas por los canales comerciales de cobertura nacional, RCN y Caracol. En los grupos de capital escolar ampliado los gustos tienden a igualarse entre niños y niñas: es el caso del popular dibujo animado producido en los Estados Unidos Bob Esponja, transmitido durante 2005, y también de ficciones contemporáneas donde la tecnología se vuelve la protagonista de la serie, como El colegio del agujero negro, Ciencia traviesa y Qué raro. En los sectores altos con acceso a TV por cable o satelital las niñas gustan de narrativas que incluyen mujeres como protagonistas, como Las chicas superpoderosas o Ginger, que se transmitían durante el trabajo de campo realizado en 2005. En la fase empírica desarrollada entre 2007 y 2008 el género también aparece como elemento mediador en las preferencias de los niños por determinados programas de televisión.

Se requiere una precisión: teniendo en cuenta sólo los programas que más menciones registraron, niños y niñas coinciden en que los dibujos animados son los que más les gustan. Sin embargo, entre los niños la preferencia por este género es mayor que entre las niñas, ya que con respecto al segundo género más nombrado, que es la telenovela, las niñas mencionan este tipo de programas casi en igual frecuencia que los dibujos animados. En el caso de Puerto Tejada la preferencia que tienen las niñas por las telenovelas es mucho más marcada que en Bogotá. Los niños de ese municipio pequeño también gustan de las telenovelas, aunque en menor proporción que las niñas. En el caso de Guambía, sólo teniendo en cuenta los programas de televisión con mayor número de menciones, las telenovelas son las más nombradas por ambos sexos, aunque los niños nombran como favoritos los dibujos animados casi en igual proporción que las telenovelas. En la fase 2 estaba de moda la novela argentina Patito feo, versión moderna de La Cenicienta, historia centrada en una niña, la cual fue fabricada especialmente para públicos infantiles, y que goza de gran popularidad especialmente entre el género femenino, desde las preescolares.

Los datos nombrados demuestran que a medida que disminuyen el grado de urbanización, el nivel socioeconómico, y el capital escolar, el género de la novela es mayoritariamente apreciado por las audiencias infantiles, y más marcadamente por las niñas. En la predisposición de los menores de sectores populares a ver la telenovela ejercen una influencia fuerte las madres y abuelas, quienes "inician" a los niños y niñas en la televidencia de este género. Hay que destacar que parece ser una constante que a los niños de todos los grupos les gusta una mayor variedad de programas que a las niñas.

De acuerdo con los resultados de la fase 1 de investigación, el género también se revela en los otros usos del tiempo libre, y en el tipo de juegos mencionados por los niños, además de lo señalado sobre el consumo de TV. No obstante los cambios en los roles femeninos y masculinos en la sociedad colombiana en las últimas décadas, -algunos de los cuales son incluso representados por imágenes de la TV- los hombres aún prefieren los carros y jugar a los "escondidos" o "pistoleros" y las niñas mencionan como favoritos algunos juegos que reproducen actividades del hogar. Y en el caso de las niñas también es más frecuente que participen en mayor proporción en las tareas domésticas, actividad que se intensifica en los estratos populares y más aún en el mundo rural. El deporte es una práctica escasa en todos los grupos sociales. Una mayor proporción de familias de los sectores altos incluye esta actividad en la agenda semanal: se refirieron a tenis, judo, equitación y natación, actividades todas que requieren tanto de entrenamiento como de sitios especializados para su práctica.

\section{Capital escolar ampliado no equivale a mayor capital económico.}

En el grupo de niños participantes, las familias que han dotado a sus hijos de un capital escolar ampliado no son las familias de mayor capital económico. La adquisición de un capital escolar mayor está en proporción directa a una historia familiar de relación con los circuitos de la cultura denominada "erudita”, y a la vez con un proyecto educativo explícito y fuerte que la familia deliberadamente determina cumplir, y que le impone unos "programas" específicos en la organización tanto del tiempo familiar, así como también la destinación de recursos humanos y económicos a la obtención de metas determinadas en la educación de los hijos dentro del sistema escolar formal, a la capacitación de ellos en competencias adicionales como una segunda o tercera lengua, las artes o la informática, y a la formación de valores para la vida. Son relevantes para examinar lo anterior los casos en los que los padres o madres cuentan que han tenido que "sacrificar el ganar plata para darle más tiempo a los hijos". Estas metas requieren a veces la postergación o la supresión de objetivos de lucro económico de la familia, puesto que ejercen presiones y cambios a nivel del tiempo que los padres deben pasar con los hijos, en oposición a dedicarse a actividades laborales que aumenten sus ingresos. 
Lo anterior, en lo que respecta a las categorías y métodos de investigación, equivale a que las clasificaciones relativas a "clase social", que se establecen por ubicación en un estrato socioeconómico, se han problematizado con base en elementos de la historia familiar de relación con la cultura erudita, sus medios, agentes, productos y las competencias e ideales que ella legitima. Esto remite a las definiciones de "capital escolar" y "capital cultural" de Bourdieu, como recursos que no equivalen a propiedad o ingresos de los padres, pero que en el futuro sí podrán garantizar a los hijos que acumulen tal capital una posición que sea valorizada y retribuida con un elevado nivel de renta en el mercado laboral. La acumulación de capital cultural por los hijos depende de la socialización en familias que a su vez han acumulado capital cultural, y que sean capaces de transmitir a las nuevas generaciones determinados recursos y facilidades de acceso a los bienes culturales y a los conocimientos requeridos.

Los siguientes enunciados sintetizan lo expuesto hasta aquí:

- Los consumos de medios son diferenciados, y una de las principales "mediaciones" que interviene en estos consumos es el capital escolar.

- Los consumos diferenciados de medios incluyen diferencias en la televidencia de noticieros y en las relaciones de los niños con los géneros informativos.

- Los sectores pobres de la sociedad consumen mayoritariamente la "cultura internacional popular", lo cual marca diferencias en el tipo de conocimientos y competencias que adquieren.

- La televisión y otros medios no tienen eficacia por sí solos; requieren de procesos de intercambio lingüístico (con los adultos, con los pares en edad) para ejercer su influencia en la percepción de la realidad o en la construcción de conocimientos por los niños y niñas.

- Las tecnologías de la comunicación y la información gozan de prestigio simbólico entre los adultos y entre los menores, y su disponibilidad de ellas es hoy tanto un insumo para las competencias que la escuela y el mercado laboral exigen como otro elemento de distinción social.

- Los grupos de niños y niñas indígenas y afrocolombianos muestran particularidades en sus interpretaciones de la realidad, y evidencian las consecuencias de la exclusión social y la discriminación a las que han sido sometidos.

- Aunque en un contexto de diferenciación social como el colombiano los sectores de mayores ingresos sí tienen más oportunidades y medios de acceso a educación de calidad, la acumulación de un mayor capital escolar no corresponde al mayor capital económico sino tanto a la historia familiar de relación con la cultura erudita, así como también a un conjunto de condiciones favorables que los padres hacen disponibles para sus hijos, en función de que ellos logren las competencias que el sistema escolar exige y la titulación.
Las diferenciaciones en cuanto al tipo de medios masivos, programas y textos con los cuales cada grupo de niños se relaciona cotidianamente y sus intercambios lingüísticos con los adultos interesan aquí no solo en función de cómo son las relaciones de los sectores populares con la oferta mediática, sino en cuanto también arrojan luz sobre los procesos desiguales de distribución del conocimiento social y sobre cómo se gesta la socialización política de las nuevas generaciones.

El debate no puede ser entre una postura a favor de la cultura erudita y otra a favor de la cultura popular, pues el enunciado sería demasiado simple. Mirando con beneplácito la expansión de los bienes culturales el trabajo cultural tendría que ser a favor de que los sectores populares puedan apropiarse también de los bienes restringidos y de las competencias necesarias para usarlos, disfrutarlos y producir mejoras en su calidad de vida. O solucionar problemas utilizando los recursos culturales y sociales de que disponen. No es posible tampoco clasificar dentro de un mismo cajón a todos los bienes culturales restringidos en cuanto a su potencial emancipatorio. Hay que prever que no se promuevan representaciones con halo romántico ni de los sectores populares ni de los géneros populares. Cabe aquí lo que ha planteado Jesús Martín Barbero sobre el trabajo de Eric Maigret. ${ }^{32}$ Sostiene que este analista aborda "la economía política de la comunicación" sacándola de su vertiente puramente descriptiva y de denuncia, para reubicarla sobre pistas y autores que no están de moda pero sí atentos a la complejidad de los cambios que atraviesan las industrias culturales. Es posible, escribe Martín Barbero, que los enfoques de Maigret permitan complejizar los debates, para distanciarlos de los extremos tanto "conservadores" (defensa a ultranza de la cultura erudita) como "populistas" (celebración acrítica de las industrias culturales masivas), y a la vez revisar de manera compleja las implicaciones socioeconómicas y políticas de los procesos comunicativos y culturales. ${ }^{33}$ 


\section{Notas:}

${ }^{1}$ Artículo basado en la investigación de M. López de la Roche (2010), Representações sociais construídas por audiências infantis a partir das "mediações" promovidas pela mídia e tecnologias da comunicação, Universidade Estadual de Campinas, Instituto de Filosofia e Ciências Humanas, Campinas, Brasil, tesis doctoral, sin publicar. Se aludirá a las dos fases de trabajo de campo: la primera durante 2004-2005 y la segunda 2007-2008.

2 Una versión previa y sintética de este texto fue publicada como “ ¿Las audiencias infantiles aprenden con los medios? Innovaciones tecnológicas y viejos debates”, En: Comunicar. Revista científica de comunicación educación, n 30, v.XV, Marzo Huelva, España, pp. 55-59. El texto completo hace parte del trabajo Noticias y chocolates: saberes y sabores con los niños y las niñas, módulo 1 , de una serie de 5, que fueron entregados a la Comisión Nacional de TV como resultado de la investigación sobre informativos e infancia, parte del Programa de Investigaciones Académicas 2006. La serie no ha sido impresa, aparece en el portal de la CNTV: www.cntv.org.co/cntv_bop/estudios/academicas/univalle_modulo_1.pdf

3 La perspectiva culturalista organiza el estudio de las audiencias basándose en una definición del contexto dentro del cual el proceso de comunicación ocurre. Asume la audiencia como un espacio o contexto socio-cultural: los procesos de comunicación mediática se realizan en circuitos localizados de relaciones sociales, interacciones cotidianas y filiaciones particulares tales como clase o religión; también incluye la noción de "subcultura” como pertinente. La perspectiva culturalista, señala Virginia Nightingale (2003) permite retomar para la investigación de audiencias varias disciplinas y métodos de las ciencias humanas y sociales, y también teorías relevantes sobre procesos culturales.

${ }^{4}$ Se usa "mediaciones" tomando como referentes a Martín Barbero, J. (1987), De los medios a las mediaciones, México: Gustavo Gili, y Orozco, G. (1991), Recepción Televisiva: tres aproximaciones y una razón para su estudio, México: Universidad Iberoamericana. Una revisión reciente del concepto de "mediaciones" hecha por varios autores puede consultarse en la revista Anthropos n 219. Jesús Martín Barbero, Comunicación y culturas en América Latina (2008), Barcelona.

${ }^{5}$ Puerto Tejada es un municipio de 45.000 habitantes.

${ }^{6}$ Los atributos negativos en referencia a la guerrilla y positivos en referencia al ejército ya habían sido identificados en un estudio anterior: López, M. et al (2000), Los niños como audiencias. Investigación sobre recepción de medios, Proyecto Infancia, Bogotá: Ministerio de Comunicaciones de Colombia-ICBF.
${ }^{7}$ De los 9 grupos de niños involucrados en el trabajo empírico tan solo uno demostró una percepción confusa acerca del conflicto armado colombiano, o sea aproximadamente un $11 \%$ de los participantes. (niños de 8 a 10 años de un colegio urbano de Cali, de capital escolar ampliado, que se ha denominado "Plantel 1" en la nomenclatura de este trabajo). Este caso aislado se explica en parte por ser niños de corta edad, que pueden haber sido "protegidos" por sus padres respecto a las noticias y al "clima” del conflicto armado. Por otro lado, su grado alto de escolarización los hizo siempre hablar de la guerra en referencia más a sus lecturas previas, y a textos de cine y TV, que a un hecho social cercano a sus vidas. Sin embargo, un dato importante que hay que problematizar es que el trabajo de campo se llevó a cabo en 2004-2005, fechas en las que el conflicto no había recibido tanta publicidad como en el segundo período de gobierno de Uribe, situación de "publicidad" que se ha incrementado por la liberación de secuestrados y las grandes marchas anti-secuestro que se hicieron el 4 de febrero de 2008, estimuladas por la TV y radio hegemónicas.

8 Herrán, M.T. et al (2005), Cubrimiento periodístico responsable del desplazamiento forzado interno, Bogotá: Medios para la Paz.

9 Categoría acuñada por Renato Ortiz en Mundialização e cultura (1994),São Paulo: Brasiliense.

${ }^{10} \mathrm{Al}$ igual que en la investigación anterior los personajes reconocidos fueron Shakira y Michael Jackson, provenientes de las industrias culturales transnacionalizadas: López, M. et al (2000), Los niños como audiencias. Investigación sobre recepción de medios, Proyecto Infancia, Bogotá: Ministerio de Comunicaciones de Colombia -ICBF.

11 Esta parte alude al ejercicio de explorar el reconocimiento, por parte de los niños y las niñas, de un conjunto de imágenes y de términos. Las imágenes mostraban a: Vicky Dávila (presentadora de un noticiero), en Bogotá los jugadores del equipo de fútbol Nacional y Edgar Rentería (jugador colombiano de baseball) en Guambía y Puerto Tejada, Francisco Santos (vicepresidente de Colombia), Hugo Chávez (Presidente de Venezuela), Andrea Serna (presentadora de realities en la TV) y las letras www.

Los términos incluidos para examinar si sabían acerca de ellos fueron: SIDA, I.V.A., calentamiento global y parapolítica.

12 La primera era la fórmula vicepresidencial de Ingrid Betancourt. La segunda, una excongresista. 
${ }^{13}$ Se consultó un listado de temas en la fase 1 y otro listado de temas en la fase 2. Se citan aquí los ejemplos de la fase 2 por abreviar la presentación de datos empíricos. Sin embargo, los hallazgos de ambas fases coinciden.

14 Los estándares de calidad se refieren a factores como la infraestructura escolar (incluidos los equipamientos audiovisuales e informáticos), el grado de escolaridad del profesorado, y las modalidades pedagógicas utilizadas, entre otros, los cuales son hoy evaluados por el estado.

${ }^{15}$ Sarlo, B. (1994), Escenas de la vida postmoderna. Intelectuales, arte y videocultura en la Argentina, Buenos Aires: Ariel.

${ }^{16}$ Sodré, M. (2002), Antropológica do espelho, Petrópolis: Editora Vozes.

${ }^{17}$ Sodré, M., Ibid .

18 Se debe tener en cuenta que cada uno de los niños encuestados mencionaron al menos 2 programas favoritos. Por lo tanto, el número de menciones hace referencia al número de respuestas y no al número de niños encuestados.

19 Martín Barbero, J. (2002), La educación desde la comunicación, Bogotá: Norma.

20 FUENZALIDA, Valerio (2008) "Cambios en la relación de los niños con la televisión”, en Comunicar . Revista científica iberoamericana de comunicación y educación, n 30, VOL XV (2008). También Televisión y cultura cotidiana (1997), Santiago de Chile: Corporación de Promoción Universitaria CPU.

21 Fuenzalida, V. (2003), Evolución y nuevas posibilidades en televisión educativa: la televisión que necesitan los niños, Documento en línea. Citado el 28 de abril de 2008. Disponible en internet: http: / /www.comminit.com/es/node/149903. También Fuenzalida (2008).

${ }^{22}$ Fisherkeller, J.E. (1999), "Learning about Power and Success: Young Urban Adolescents Interpret TV Culture”, En:The Communication Review, Vol 3, n 3.

${ }^{23}$ Barbary, O. y Urrea, F. (2004), Gente negra en Colombia. Dinámicas sociopolíticas en Cali y el Pacífico, Medellín: CIDSE UNIVALLE-L'Institut de Recherche poru le Développement de France-COLCIENCIAS.

24 HURTADO SAA, Teodora (2007), Comunicación, etnias y multiculturalidad en la radio comunitaria, publicación del PLAN DE FORMACIÓN PARA RADIOS COMUNITARIAS EN COLOMBIA, Ministerio de Comunicaciones-Universidad del Valle, Cali.
25 COMPARTEL es un programa creado por el Ministerio de Comunicaciones de Colombia, cuyo objetivo es permitir que las zonas apartadas y los estratos bajos del país se beneficien con las tecnologías de las telecomunicaciones como la telefonía rural y el servicio de internet banda ancha.

${ }^{26}$ Departamento Administrativo Nacional de Estadística, Bogotá, datos consultados el 25 de marzo de 2009 en www.DANE. gov.co.

27 La Concentración Escolar Las Delicias tiene 204 alumnos, todos guambianos, que se distribuyen entre 1 curso de preescolar, 2 primeros, 2 segundos, 3 cuartos y 3 quintos.

28 Toribío. La guerra en el Cauca I y II, documentales producidos por Hollman Morris sobre el conflicto armado en Colombia transmitidos los días jueves 5 y jueves 12 de mayo de 2005 por Canal 1, en el programa denominado Contravía.

${ }^{29}$ Hopenhayn, M. (2005), América Latina desigual y descentrada, Bogotá : Norma.

30 Sodré, M., Op. cit.

31 El dato sobre escolares que terminan la secundaria también es de Hopenhayn, en: Hopenhayn, M. (2005), Ibid.

32 MAIGRET, Eric (2005) Sociología de la comunicación y de los medios, Fondo de Cultura Económica, Bogotá. (Edición original 2003, Armand Colin, Paris).

33 Se amplía en esta nota final lo relativo al trabajo empírico, aunque por espacio es necesario hacer un recuento parcial: Se hizo en 2 fases. La primera fue realizada durante 2004- 2005 con un pequeño grupo de profesionales, constituido mediante apoyo financiero de COLCIENCIAS. La segunda fase se hizo en 2007-2008, y tuvo como fin profundizar en algunos puntos de la precedente, y completar los análisis ya esbozados. Se financió como un proyecto del Programa de Investigaciones Académicas de la Comisión Nacional de Televisión CNTV, convocatoria 2006.

Para determinar los grupos de niños y los sitios del trabajo de campo tanto en la fase 1 como en la 2 se tuvo en cuenta que uno de los propósitos del estudio fue identificar si las representaciones sociales de los distintos grupos son expresivas de su particular ubicación socio-cultural. Para esto se escogieron grupos que pudieran ofrecer contrastes, así:

-diferenciación en cuanto a estratos socioeconómicos -diferenciación en capital cultural/escolar de los niños -diferenciación geográfica-cultural: campo/ciudad -diferenciación como grupos étnicos 
La investigación se propuso examinar la "influencia" de los medios de comunicación en las lecturas de la realidad de los niños, evaluando dicha influencia dentro de un conjunto de "mediaciones" que intervienen en el proceso de construcción de la realidad. Sin embargo, aunque el estudio tuvo en cuenta todas las mediaciones citadas, priorizó la de "capital escolar". Es decir, le otorgó especial atención a ésta, para lo cual se dispusieron estrategias metodológicas específicas destinadas a la recolección de información durante el trabajo de campo. Así mismo, a esta mediación se le asigna un lugar principal en el análisis.

Se ha recurrido en este estudio a algunas categorías y tesis de Pierre Bourdieu. Se plantea la relación entre capital escolar/capital cultural y "elecciones culturales" de los sujetos, y se cuestiona la "naturalización" del gusto en relación con los bienes culturales, poniendo en evidencia su carácter de aprendido. Como se dijo antes, aunque esta investigación no descuida las otras "mediaciones" identificadas como importantes en la medida en que operan sobre el sujeto social, la disponibilidad de capital escolar es una de las mediaciones principales que se examina. En consecuencia,

la investigación se estructuró basándose en la agrupación de todos los niños participantes en dos grandes categorías diferenciadas:

-niños con capital escolar restringido (CER)

-niños con capital escolar ampliado (CEA)

Para ser incluido en la categoría de CEA un niño o niña debía cumplir con el siguiente conjunto de características, las cuales fueron indagadas a través de entrevistas estructuradas, con un número de niños en cada colegio y escuela, las cuales se realizaron con las denominadas "Fichas de identificación del niño", y "Fichas de capital cultural”:

1. Ambos padres con estudios universitarios

2. Evidencia de que el niño tiene muy buenas competencias para la lectura, de que le gusta leer, y de que lee regularmente.

3. Evidencia de que el niño participa de las actividades de circuitos culturales denominados "cultos", como la asistencia a conciertos de "música culta", a museos, a exposiciones de arte, a teatro o a actividades similares. Igualmente, este requisito puede cumplirse a través de la participación del niño en clases formales de algún tipo de práctica artística como música, pintura o danza, y/o mediante su matrícula en cursos de lenguas extranjeras o algún otro aprendizaje complementario al currículo escolar básico.

4. Disponibilidad de un computador en casa, y de horas de uso para el niño o niña.

El haber escogido grupos "extremos" plantea algunas limitaciones: niños con capital escolar restringido pertenecientes a sectores sociales subalternos, en oposición a niños con capital escolar ampliado pertenecientes a sectores sociales de altos ingresos y de elites profesionales; en el futuro tendrá que refinarse esta tipología para incluir categorías intermedias. Sin embargo, para los propósitos de este estudio la elección de dos "tipificaciones" bastante distanciadas una de la otra fue necesaria, pues permite identificar con nitidez factores que pueden ser sometidos más adelante a mayor observación y estudio para complejizar el "mapeo” y los análisis resultantes. De todas maneras se subraya aquí que aún dentro de la oposición "capital cultural restringido" y "capital cultural ampliado" la investigación logra análisis detallados que permiten deconstruir la oposición binaria, y mostrar las particularidades de los distintos grupos de niños participantes, de acuerdo con las características socioculturales y geográficas de cada colectividad.

\section{Bibliografía}

ANG, Ien (1995) "The nature of the audience", in DOWNING, John et al (eds.) Questioning the Media, Sage, London.

APPLE, Michael (1997), "Educación, identidad y papas fritas baratas”, en GENTILI, Pablo (com.), Cultura, política y currículo, Losada, Buenos Aires.

BARBARI, Olivier y URREA, Fernando (eds.) 2004, Gente negra en Colombia. Dinámicas sociopolíticas en Cali y el Pacífico, Centro de Investigaciones y Documentación Socioeconómica de la Universidad del Valle CIDSE, L'Institut de Recherche pour le Developement de Francia IRD, y COLCIENCIAS, Editorial Lealón, Medellín.

BOURDIEU, Pierre (1999), ¿Qué significa hablar?, 2ª edición, Ediciones Akal S.A., Madrid.

BOURDIEU, Pierre(1998) La distinción, Taurus, Madrid (Edición previa 1988 en español. Edición original 1979 La distinction, Editions de Minuit).

BOURDIEU, Pierre, CHAMBOREDON, Jean-Claude y PASSERON, Jean-Claude, (2001), La reproducción, Editorial Popular, Madrid.

BUCKINGHAM, David (2000) The Making of Citizens. Young People, News and Politics, Routledge, London and New York. 
BUCKINGHAM, David (2002) Crecer en la era de los medios electrónicos, Ediciones Morata, La Coruña, España. (Edición original 2000 After the Death of Childhood. Growing up in the Age of Electronic Media, Blackwell, Great Britain).

FISHERKELLER, Jo Ellen (1999), "Learning about Power and Success: Young Urban Adolescents Interpret TV Culture”, The Communication Review, Vol 3, n 3.

FISKE, John (1987) Television Culture, Methuen, London.

FUENZALIDA, Valerio (2008) “Cambios en la relación de los niños con la televisión”, en Comunicar . Revista científica iberoamericana de comunicación y educación, n 30, VOL XV (2008).

FUENZALIDA, Valerio (2002) Televisión abierta y audiencia en América Latina, Norma, Buenos Aires.

FUENZALIDA, Valerio (1997) Televisión y cultura cotidiana, Corporación de Promoción Universitaria CPU, Santiago de Chile.

GNECCO, Cristóbal (2006) “Discursos sobre el otro: antropología de la alteridad”, Departamento de Antropología, Universidad del Cauca, documento no publicado.

GONZÁLEZ, Julián et al.(2005), La representación de lo indígena en los medios de comunicación. En minga con los pueblos indígenas y por el derecho a su palabra, Hombre Nuevo Editores, El Espectador-ASCÚN.

HOPENHAYN, Martín, (2005) América Latina desigual y descentrada, Norma, Bogotá.

HUERGO, Jorge, (2008) "La relevancia formativa de las pantallas", en Comunicar . Revista científica iberoamericana de comunicación y educación, n 30, VOL XV.

HUERGO, Jorge y FERNÁNDEZ, María Belén (2000) Cultura escolar, cultura mediática/ Intersecciones, Universidad Pedagógica Nacional, Bogotá.

HURTADO SAA, Teodora (2007), Comunicación, etnias y multiculturalidad en la radio comunitaria, publicación del PLAN DE FORMACIÓN PARA RADIOS COMUNITARIAS EN COLOMBIA, Ministerio de Comunicaciones-Universidad del Valle, Cali.

KATZ, Elihu ( 1997), « La herencia de Gabriel Tarde. Un paradigma para la investigación sobre la opinión y la comunicación », en DAYAN, Daniel, (1997) En busca del público. Recepción, televisión, medios. Gedisa, Barcelona.(Edición original 1993 Hermès 11-12. A la recherche du public, CNRS Editions, Paris)

LÓPEZ DE LA ROCHE, Fabio (2002) “Opinión, información y ficción en los medios colombianos”, Revista Foro n 45, Bogotá.

LÓPEZ DE LA ROCHE, Maritza (2008) “¿Aprenden las audiencias infantiles con los medios?”, en Comunicar . Revista científica iberoamericana de comunicación y educación, n 30, VOL XV.

LÓPEZ DE LA ROCHE, Maritza et al (2000) Los niños como audiencias. Investigación sobre recepción de medios, Proyecto Infancia Ministerio de Comunicaciones de Colombia -ICBF, Bogotá.

MACÉ, Eric (1993) "La televisión del pobre. La participación del público”, en Hermès 11-12. A la recherche du public, CNRS Editions, Paris. Edición en español: DAYAN, Daniel, (1997) En busca del público. Recepción, televisión, medios. Gedisa, Barcelona.

MARTÍN BARBERO, Jesús (1987) De los medios a las mediaciones, Gustavo Gili, México. MARTÍN BARBERO, Jesús (2002) La educación desde la comunicación, Norma, Bogotá.

MARTÍN BARBERO, J. (2008), "Estallido de los relatos y pluralización de las lecturas", en Comunicar . Revista científica iberoamericana de comunicación y educación, n 30, VOL XV.

MOSQUERA, Claudia , PARDO, Mauricio y HOFFMAN, Odile (2002) Afrodescendientes en las Américas. Trayectorias sociales e identitarias, Universidad Nacional de Colombia-Institut de Recherche pour le Development IRD/Instituto Latinoamericano de Servicios Legales Alternativos, Bogotá.

MUELAS, Lorenzo y URDANETA, Martha, La fuerza de la gente. Juntando recuerdos sobre la terrajería en Guambía Colombia, Instituto Colombiano de Antropología e Historia, 2005. 
NIGHTINGALE, Virginia (1999) El estudio de las audiencias. El impacto de lo real. Paidós Comunicación, Buenos Aires (Original Edition (1996) Studying Audiences. The Shock of the Real. Routledge, London/New York)

NIGHTINGALE, Virginia, (2004) "Contemporary Television Audiences: Publics, Markets, Communities and Fans”, en DOWNING J. (ed.), Sage Handbook of Media Studies, Sage, Thousand Oaks, London and Delhi, pp.227-249.

NIGHTINGALE, Virginia, (2003) “The "Cultural Revolution” in Audience Research", en VALDIVIA, A. (ed.), A Companion to Media Studies, Blackwell, London, pp 360-381.

OROZCO, Guillermo (2001) Televisión, audiencias y educación, Norma, Buenos Aires.

OROZCO, Guillermo (1991) Recepción Televisiva: tres aproximaciones y una razón para su estudio, México, Universidad Iberoamericana.

ORTIZ, Renato(1999) "Diversidad cultural y cosmopolitismo”, en Cultura y globalización, Martín Barbero et al. (eds), Universidad Nacional de Colombia-CES, Bogotá.

ORTIZ, Renato(1997) Mundialización y cultura, Alianza, Buenos Aires. (Edición original 1994, Mundialização e cultura, Brasiliense, São Paulo).

ORTIZ, Renato (1991) Cultura e modernidade, Sao Paulo: Editora Brasiliense.

PORTO, Tânia (2000) A televisão na escola...Afinal que pedagogia é esta? JM Editora, São Paulo.

PORTO, Tânia(2001) "As mídias na escola: uma pedagogia da comunicação para formação docente em serviço”, in PORTO, Tânia (org.) Saberes e linguagens de educação e comunicação, Universidade Federal de Pelotas, Brasil.

SCHMUCLER, Héctor, (1997) Memoria de la comunicación, Editorial Biblos, Buenos Aires.

SILVERSTONE, Roger (1994) Televisión and Everyday Life, Routledge, London.

SARLO, Beatriz (1994) Escenas de la vida postmoderna. Intelectuales, arte y videocultura en la Argentina, Ariel.

SARLO, Beatriz (1998) La máquina cultural. Maestras, traductores y vanguardistas, Buenos Aires: Ariel.

SODRÉ, Muniz (2002) Antropológica do espelho, Editora Vozes, Petrópolis.

TORRES, William F. (2001), "Generar competencias culturales? Retos de la escuela y los medios para formar sujetos en medio de la guerra colombiana”, HERRERA, Martha y JILMAR DIAZ, Carlos (comps.), Educación y cultura política, Universidad Pedagógica Nacional-Plaza y Janés Editores, Bogotá.

VIVAS, Harvy (2008) Educación, desigualdad y democracia, Documento de trabajo No 118, Cali: CIDSE Facultad de Ciencias Sociales y Económicas, Universidad del Valle.

\section{Documentos Adicionales}

Children Watching War, (2004) Bundeszentrale für politische Bildung, International Central Institute forYouth and Educational Television, Munich, Germany.

Children's Views about Media Harm, Monograph 10 (2000) University of Western Sydney-Australian Broadcasting Authority, Sydney.

Cubrimiento periodístico responsible del desplazamiento forzado interno, (2005) Medios para la Paz, Bogotá.

DELGADO PARRA, María Concepción, (Maestra en Estudios Político y Sociales de la UNAM, México) "El criterio amigo-enemigo en Karl Schmitt", en Cuaderno de materiales n 14, http://www. filosofia.net/materiales/num/num14/n14d.htm

Revista Anthropos n 219. Jesús Martín Barbero, Comunicación y culturas en América Latina (2008), Barcelona. 